\title{
US GAAP Conversion To IFRS: A Case Study Of The Income Statement
}

Peter Harris, New York Institute of Technology, USA

Liz Washington Arnold, Military College of South Carolina, USA

\begin{abstract}
International Reporting Standards (IFRS) has become the required framework for most of the world financial market economies as of January 1, 2011. In the United States, US Generally Accepted Accounting Principles (GAAP) is still required. However, plans are presently in place by the SEC to abandon US GAAP and to adhere to IFRS requirements by as early as for the period ending December 31, 2014. This case study requires the student to transform a US GAAP presented Income Statement to IFRS. This case study is most suitable for an Intermediary Accounting or a Financial Analysis class at the graduate level.
\end{abstract}

Keywords: US GAAP; IFRS; LIFO; Fair Market Value Accounting; Asset Impairment

\section{INTRODUCTION}

FRS International Reporting Standards (IFRS) has presently been adapted by most countries that have a stock exchange. In the United States, however, companies report on several different principles-based methods, including, but not limited to, US GAAP and IFRS, which makes comparability, understandability and the presentation of financial data very difficult.

Much of the current financial crisis has been blamed on the inability to understand financial reporting and the ability to somehow circumvent rules due to the difficult and inconsistent accounting financial statement requirements.

The solution proposed by the SEC, and other worldwide agencies, is to have a single, conforming set of accounting principles which every publically traded company in the world would adhere to in presenting financial information. The solution has been the adaption of IFRS, and this action has been implemented by most countries worldwide, such as Europe, Canada and Australia.

The US is in the transformation stage and it is expected that IFRS will be in place by as early as 2014. As such, it is important to introduce IFRS accounting rules in the college curriculum and make it a major component of accounting classes. This case study takes a US GAAP-prepared Income Statement and, based on the facts of the case, requires students to prepare an IFRS based Income Statement. The need to understand both US GAAP and IFRS rules is required to adequately address this case study.

\section{BACKGROUND}

AXE Corp, a publically traded NASDAQ company (symbol AXEC), is a manufacturer of electrical light bulbs. Its main headquarters is based in Denver, Colorado, and the company has been operating since 1976. The company sells light bulbs to the retail market on a world-wide basis. Its major clientele is Home Depot and Lowes and has captured about 10 percent of the world market of light bulbs sales. Its stock sells at 25 US Dollars per share and its 52-week price range is between 18.75 and 27.85 US Dollars, with a market cap of 8.6 billion dollars.

Their financial statements presented below, for the Year Ending December 31, 2011, have been prepared using US GAAP. The controller would like to begin to see the effects of using IFRS on the Income Statement and 
has been assigned this task. The company would like to adapt IFRS by as early as next year as it is considering a new stock issue in the London Stock Exchange, which requires IFRS compliance.

\section{FINANCIAL STATEMENTS}

\section{Balance Sheet (in 000's)}

As of 12/31/2011

\begin{tabular}{|c|c|c|c|}
\hline \multicolumn{2}{|l|}{ ASSETS } & \multicolumn{2}{|c|}{ LIABILITIES AND SHAREHOLDERS EQUITY } \\
\hline Current Assets & & Current Liabilities & \\
\hline Cash & 33,000 & Accounts payable & 20,000 \\
\hline Accounts Receivable & 25,000 & Accrued Expense & 15,000 \\
\hline Investments & 10,000 & Taxes payable & 5,000 \\
\hline Inventory (LIFO) & 50,000 & Total Current Liabilities & 40,000 \\
\hline Total Current Assets & 118,000 & & \\
\hline \multicolumn{2}{|c|}{ Property, Plant and Equipment } & Noncurrent Liabilities & \\
\hline Assets (cost) & 100,000 & Bonds payable & 50,000 \\
\hline Less: & & Total Liabilities & 90,000 \\
\hline \multicolumn{4}{|c|}{ Accumulated Depreciation $(30,000)$} \\
\hline & 70,000 & Shareholders' Equity & \\
\hline Intangible Assets & & Common Stock (\$1 par) & 50,000 \\
\hline Trademark & 5,000 & $\underline{\text { Retained Earnings }}$ & 60,000 \\
\hline \multirow[t]{2}{*}{ Goodwill } & 7,000 & & \\
\hline & 12,000 & & 110,000 \\
\hline Total Assets & $\underline{200,000}$ & $\begin{array}{l}\text { Total Liabilities and } \\
\text { Shareholders' Equity }\end{array}$ & $\underline{200,000}$ \\
\hline
\end{tabular}


INCOME STATEMENT

1/1/2011-12/31/2011

(In 000's)

\section{INCOME FROM CONTINUING OPERATIONS}

\begin{tabular}{lr} 
Sales & 250,000 \\
Cost of Goods Sold & 175,000 \\
\hline Gross profit & 75,000 \\
Selling and Administrative Expenses & 31,000 \\
(exclusive of Amortization and Depreciation) & \\
Earnings before Interest, Taxes, Depreciation and Amortization & 45,000 \\
Amortization and Depreciation Expense & 10,000 \\
\hline Earnings before Interest and Taxes & 34,000 \\
Interest Expense & 4,000 \\
\hline Income before tax & 30,000 \\
Tax Expense (30\%) & 9,000 \\
\hline Earnings from continuing operations and before & \\
Extraordinary Item & 21,000
\end{tabular}

\section{EXTRAORDINARY ITEM}

Net loss from Hurricane (net of 4,500 taxes)

Net Income

10,500

\section{ADDITIONAL INFORMATION}

1. AXE Corp. uses the LIFO method to account for its inventory. The LIFO reserve was $\$ 15,000$ at the beginning of the year and $\$ 20,000$ as of year-end.

2. Management has established that the Fair market value of Property, Plant and Equipment as of 1/1/2011 is $\$ 85,000$, resulting in a $\$ 5,000$ increase above Book Value..

3. Upon review, management has established the following Fair Market Values for the presented assets as of 12/31/2011:

Goodwill $\quad 10,000$

Trademark $\quad 10,000$

4. In 2010, there was a Goodwill impairment accounted for in the amount of $\$ 3,000$.

5. In 2008, there was a Trademark impairment of $\$ 2,000$.

6. Property, plant and equipment is depreciated over a 10 -year period using the straight line depreciated method. There is no salvage value. Amortizable Intangible assets are amortized over a 5 year period using the straight line method. No salvage value is expected.

7. Investments include Available for Sale Securities (AFS) with a Fair market Value of $\$ 10,000$ as of $12 / 31 / 2011$. The beginning of year value was $\$ 7,000$ and $\$ 2,000$ of this increase of value is due to an exchange rate gain.

8. There are contingencies of $\$ 6,000$ stemming from civil lawsuits. Legal council considers the payout slightly "more likely than not", but not highly probable.

9. The extraordinary loss was due to hurricane damage which is considered unusual and infrequent.

10. The effective tax rate for AXE is 30 percent. 


\section{REQUIRED}

For each scenario above (1 to 8$)$ :

1. Identify the similarities and differences between the Income Statement effects of US GAAP and IFRS.

2. Record the differences above, in journal entry form, to satisfy IFRS rules.

3. Prepare an IFRS Income Statement for the 2011 calendar year.

NOTE: The focus here is only on the Income Statement.

\section{SOLUTION}

\section{Parts 1 and 2 Solutions}

1. LIFO is not permitted under IFRS. As such, FIFO has to be used. The difference between the LIFO and FIFO Cost of Goods Sold is the difference between the beginning of the year and year-end differential in the LIFO Reserve. In this case, the difference will result in a decrease in Cost of Goods sold by virtue of a greater Inventory total under FIFO in the amount of $\$ 5,000$ ( $\$ 20,000$ less $\$ 15,000)$. As such, the journal entry will be:

\section{Dr. Inventory 5,000 \\ Cr. Cost of Goods Sold 5,000}

2. IFRS allows for Asset Revaluation for Property, Plant and Equipment and Intangible Assets. Both US GAAP and IFRS allow for asset impairment which is tested on an annual basis. IFRS allows for an asset reversal of impaired assets for all tangible and intangible long-term assets, excluding Goodwill. US GAAP allows for impairment, but once lowered, no reversal of impairment is allowed. In no circumstance may Property, Plant and Equipment assets or intangible assets be written above its book value under US GAAP.

\section{Resulting Accounting Treatment: US GAAP}

The impairment loss for tangible and intangible assets is recorded on the Income Statement and results in a lower carrying value on the Balance Sheet.

\section{Resulting Accounting Treatment: IFRS}

The loss is treated similar to US GAAP.

Write-up of tangible and intangible assets is recorded as comprehensive income and not on the Income Statement. Finally, reversal of losses, up to the amount of the impairment, is recorded as a reduction in loss - a gain in the Income Statement, and any excess is recorded as part of comprehensive income. Goodwill may not be reversed once impairment has occurred.

On 1/1/2011, the Property, Plant and Equipment assets were increased by $\$ 5,000$ above Book Value. For IFRS purposes, this results in an increase of depreciation expense of $\$ 500$ ( $\$ 5,000$ divided by a 10-year useful life using the straight line depreciation method).The Adjusting entry then is:

\section{Dr. Depreciation Expense 500 \\ Cr. Accumulated Depreciation 500}

The trademark had an estimated fair market value of $\$ 10,000$ as of year-end. US GAAP does not allow for reversals of previous recorded impairments. Under IFRS, the previous impairment loss will be reversed to the Income Statement, as a reduction to loss - in effect, a gain - and any excess over that is recorded as Comprehensive Income (not on the Income Statement). The adjusting entry is: 
3. Dr. Trademark 5,000

Cr. Reversal of Impairment Loss- Trademark - Income Statement 2,000

Cr. Shareholders' Equity (Comprehensive Income) 3,000

3. Finally, there is no adjustment for Goodwill as both US GAAP and IFRS have similar treatment for this intangible asset. Also note that Trademarks and Goodwill are not amortizable intangible assets due to their indefinite useful life.

4. Available For Sale Securities (AFS)

Both US GAAP and IFRS treat AFS securities similar in that they are reported at Fair Market Value at the Balance Sheet date. Any income or loss is part of comprehensive income (not Income Statement). The only difference, however, is that IFRS treats the foreign currency exchange gain or loss as an income (loss) item, which is reported in the Income Statement.

As such, $\$ 2,000$ of the increase in the AFS value, which relates to currency gain, is part of non-operating income. As such, the adjusting entry is:

4. Dr. Shareholders' Equity 2,000

Cr. Currency Exchange Rate Gain 2,000

5. US GAAP and IFRS record a contingency loss when the loss is deemed to be probable. This definition of probable differs between the two groups. US GAAP defines probable as "likely", whereas IFRS defines probable as "more likely than not". The result is that IFRS is more conservative in recognizing contingency losses. In this situation, the loss is recorded for IFRS only. The adjusting entry then is:

5. Dr. Contingency loss 6,000

Cr. Contingency Liability payable 6,000

6. Extraordinary Items - US GAAP v. IFRS

IRFS disallows extraordinary gains (losses) and, as such, is not existent. Consequently, this item needs to be part of the non-operating income (loss) schedule of the Income Statement. The gross amount of the loss, in this case, is the net of tax loss of $\$ 10,500$, divided by .7 (1 less 30 percent tax rate), resulting in a loss from hurricane - before taxes - of $\$ 15,000$.

We reclassify this loss from extraordinary to non-operating income (loss). 


\section{AXE Corp.}

Income Statement (in 000, s)

1/1/2011-12/31/2011

\begin{tabular}{lllr} 
& & IFRS & INCOME FROM CONTINUING OPERATIONS \\
Sales & US GAAP & ADJUSTMENTS & IFRS \\
Cost of Goods Sold & 250,000 & & $\mathbf{2 5 0 , 0 0 0}$ \\
Gross profit & 175,000 & $(1)(5,000)$ & $\mathbf{1 7 0 , 0 0 0}$ \\
Selling and Administrative Expenses & 75,000 & & $\mathbf{8 0 , 0 0 0}$ \\
& $\underline{31,000}$ & & $\mathbf{3 1 , 0 0 0}$ \\
\hline
\end{tabular}

$\underline{\text { (Exclusive of Amortization and Depreciation) }}$

Earnings before Interest, taxes, depreciation and Amortization 44,000

Amortization and depreciation Expense $\quad 10,000$

Earnings before Interest and Taxes $\quad 34,000$

34,000
4,000

49,000

Interest Expense

30,000

10,500

38,500

Income before Non-Operating Income and Taxes

34,500

Non-Operating Income (Loss)

1. Reversal of trademark Impairment loss

(3) $2,000 \quad \mathbf{2 , 0 0 0}$

2. Exchange rate gain on AFS

3. Contingent losses

4. Hurricane loss

(4) 2,000

2,000

(5) $(6,000)$

$(6,000)$

(6) $(15,000)$ $(17,000)$

$(15,000)$

$(17,000)$

Income before Tax

Tax Expense (30\%)

9,000

Earnings from continuing operations

21,000

17,500

Tax Expense (30\%)

\section{EXTRAORDINARY ITEM}

Net loss from Hurricane (net of 4,500 taxes)

$(10,500)$

N/A For IFRS

Net Income

$\underline{10,500}$

$\underline{12,250}$ 


\section{Part 3 Solution: IFRS Prepared Income Statement}

\section{IFRS Prepared Income Statement}

1/1/2011-12/31/2011

\section{(In 000's)}

\section{INCOME FROM CONTINUING OPERATIONS}

Sales

Cost of Goods Sold

250,000

Gross profit

Selling and Administrative Expenses

80,000

(Includes of Amortization and Depreciation expense of \$10,500)

Operating Income

Non- Operating Income (Loss):

1. Reversal of trademark Impairment loss $\quad 2,000$

2. Exchange rate gain on AFS 2,000

3. Contingent losses $\quad(6,000)$

4. Hurricane loss $\quad \underline{(15,000)}$

$\frac{(15,000)}{(17,000)}$

Earnings before Interest and Taxes $\quad 21,500$

Interest Expense $\quad 4,000$

Income before tax $\quad 17,500$

Tax Expense (30\%) $\quad \underline{5,250}$

Net Income $\quad \underline{12,250}$

\section{CONCLUSION}

IFRS is the future of world-wide financial reporting and should be included as a major part of any accounting and/or business curriculum in the US, as well as the rest of the world. This case illustrates a situation where an Income Statement is prepared using US GAAP as a basis and converting to IFRS for comparison purposes. In this case study, IFRS rules are discussed and key Income Statement similarities and differences between US GAAP and IFRS are addressed. We will follow up with other similar case studies which focus on an IFRS-prepared Balance Sheet and a Cash Flow Statement from a US GAAP prepared Financial Statement.

\section{AUTHOR INFORMATION}

Peter Harris is a Professor and Chair of the Accounting and Finance department at the New York Institute of Technology. Previously, he has worked for Ernst and Young LLP. He is an author of over 30 refereed journal articles and over 100 intellectual contributions. He has presented and continues to present seminars to nationally and globally audiences on topics relating to financial reporting and taxation. He is a member of several professional organizations. He can be reached at pharris@nyit.edu and by phone at 516-695-6707. Corresponding author.

Liz Washington Arnold is an Associate Professor of Accounting at The Citadel. She has over 25 years of corporate accounting experience and is an active member of various community and professional organization. Her research on Corporate Accounting Malfeasance and other topics appears in journals such as Accounting and Taxation, the Southeast Case Research Association Journal, and Business Education Innovations. She can be reached at The Citadel, 171 Moultrie Street, Charleston, SC 29445. E-mail: liz.arnold@ citadel.edu 


\section{REFERENCES}

1. International Financial Accounting Standards (IFRS). IAS numbers: 2, 3, 36, 37, 38, 39.

2. PWCoopers.org

3. Revise, Collins, Johnson, Financial Reporting and Analysis, 3rd Ed. Pearson, Prentice, Hall, 2004.

4. The Analysis and Uses of Financial Statements, White, Sondhi, Fried, Wiley, 3rd Edition, 2008.

5. U.S Generally Accepted Accounting Principles (US GAAP). ASC Numbers: 320, 330, 360, 410, 985. 